\title{
COMPARISON OF TRAP AND BAITED STICK CATCH EFFICIENCY FOR NOBLE CRAYFISH (ASTACUS ASTACUS L.) IN THE COURSE OF THE GROWING SEASON
}

\author{
T. POLICAR AND P. KOZÁK
}

University of South Bohemia České Budějovice, Research Institute of Fish Culture and Hydrobiology in Vodňany, Zátiší 728/II, 38925 VODŇANY, Czech Republic.

E-Mail: policar@vurh.jcu.cz

Reçu le 19 octobre 2004

Accepté le 8 mars 2005

Received October 19, 2004

Accepted March 8, 2005

\begin{abstract}
Noble crayfish (Astacus astacus) were caught using traps and baited sticks in Světlohorská reservoir in the Czech Republic, and the catch efficiency and size and sex composition in catches were compared during the growing season (May-September). One trapping period per month (1.5 hour from 6-7: 30 pm) was applied.

Trap catches were significantly higher in September compared to the other months, and baited stick catches were significantly higher in May, June and September.

Baited sticks were significantly more effective than traps in all months except in July. Males dominated in all catches, except in September trap catches. Females were totally absent in traps in June, July and August. Baited sticks caught females more successfully than traps, especially females with eggs. Traps did not catch any females with eggs.
\end{abstract}

Males and females caught by baited sticks were of larger size range (range of body length $60-125 \mathrm{~mm}$ ) than those caught by traps (range of body length $75-120 \mathrm{~mm}$ ) however, there were no significant differences in mean size.

Due to high catch efficiency, baited sticks may be considered as an appropriate catching gear in crayfish monitoring projects, especially when a short-time catching effort is required.

Key-words: Astacus astacus, noble crayfish, catch efficiency, size and sex composition, trap, baited stick, growing season.

\section{COMPARAISON DE L'EFFICACITÉ DE PIÈGES ET DE BÂTONS AVEC APPÂTS SUR LA CAPTURE DE L'ÉCREVISSE NOBLE (ASTACUS ASTACUS L.) PENDANT LA SAISON DE CROISSANCE}

\section{RÉSUMÉ}

Des écrevisses nobles (Astacus astacus) ont été capturées à l'aide de pièges et de bâtons avec appâts dans le réservoir Světlohorská. L'efficacité de la technique de capture, la taille et le sex-ratio des différentes prises ont été comparées tout au long de la saison de croissance (Mai à Septembre). Une pêche par mois (d'une durée $1 \mathrm{~h} 30$, de $18 \mathrm{~h}$ à $19 \mathrm{~h} 30$ ) a été pratiquée tout au long de cette période. 
C'est en septembre que l'on a capturé le plus d'écrevisses, que ce soit à l'aide des pièges ou des bâtons avec appât. C'est en juillet que la capture d'écrevisses à l'aide des pièges a été la moins efficace, et en août celle à l'aide de bâtons avec appât. La plus grande CPUE des pièges et des batons avec appâts a été réalisée en septembre. La plus petite l'a été en juillet.

Les bâtons avec appâts ont été plus efficaces que les pièges sauf en juillet. Les mâles ont dominé dans toutes les captures, à l'exception des captures par pièges en septembre. Les femelles ont été totalement absentes des pièges en juin, juillet et août. Les bâtons avec appât sont plus efficaces que les pièges pour capturer les femelles, particulièrement celles qui portent des œufs. Les pièges n'ont pas capturé de femelles portant des œufs.

Les mâles et les femelles capturés à l'aide des bâtons avec appât étaient plus gros (longueur du corps de 60 à $125 \mathrm{~mm}$ ) que ceux capturés à l'aide des pièges (longueur du corps de 75 à $120 \mathrm{~mm}$ ).

Mots-clés : Astacus astacus, écrevisse noble, efficacité des captures, distribution des tailles et des sexes, piège, bâton avec appât, saison de croissance.

\section{INTRODUCTION}

Commercial catching of noble crayfish for consumption probably started at the end of Middle Ages (SWAHN, 2004). The demand for noble crayfish increased and commercial harvesting of this crayfish became a big industry in the nineteenth century (LEHTONEN, 1974). Noble crayfish were harvested mainly in Russia, Sweden, Finland, Germany, Poland and Denmark (SKURDAL and TAUGBØL, 2002). The introduction of crayfish plague in 1860 ravaged the previous distribution of noble crayfish in Europe (HOLDICH, 1988). At present, the noble crayfish harvest is less than $10 \%$ of the historic pre-plague record (WESTMAN, PURSIAINEN and WESTMAN, 1990; SKURDAL et al., 1999). The present total European annual catch of noble crayfish is estimated to be approximately 220 tons, which is approximately 2 to $3 \%$ of total European catch of all crayfish species (SKURDAL and TAUGBØL, 2002). Noble crayfish are captured not only for consumption but also for breeding (KELLER, 1987) and restocking (HAGER, 1996).

Crayfish are caught using a wide array of methods and equipment described in KRUPAUER (1968) and WESTMAN, PURSIAINEN and WESTMAN (1990). Catching by hand, baited stick or a net balance yielded lower results with greater physical effort than catching by traps (WESTMAN, PURSIAINEN and WESTMAN, 1990). With the strong rise in consumption of noble crayfish at the end of the nineteenth century, these methods were no longer sufficient and crayfish traps were introduced (LEHTONEN, 1974). However, nowadays recreational catching for home consumption also includes capture by hand, baited sticks and nets (WESTMAN, PURSIAINEN and WESTMAN, 1990). In the past, traps for catching crayfish were wooden, made from laths and ribs, and difficult to transport (CUKERZIS, 1988). Today the traps are usually made from plastic, or netting with springy wire (LEHTONEN, 1974; ROMAIRE and PFISTER, 1983; CUKERZIS, 1988; FEDOTOV, 1993; WESTMAN, 1991; KOZÁK, STUPKA and HAMÁČKOVÁ, 2001). There are two main types of traps: upright traps with the entrance on the top and cylindrical traps with a side entrance (WESTMAN, 1991; HOLDICH, 2002).

In the Czech Republic, noble crayfish were exploited in the same way as in other European countries during the beginning of the last century. There were 577 crayfish collecting ponds in the Czech Republic and annual harvest of noble crayfish achieved 4 tonnes at the beginning of the last century (KRUPAUER, 1968). At present, the noble crayfish are endangered, protected by act No. 114/92 Sb. and put on the national Red List (ADÁMEK, 1998). In the Czech Republic noble crayfish are not used for commercial exploitation and they are the subject of zoological and ecological studies only. A strong 
legislation without any effective conservation actions led to a situation where at present, nearly $80 \%$ of young people have never seen crayfish in natural waters of Czech Republic (ĎURIŠ and KOZÁK, 2000).

The goal of this study was to compare the catch efficiency and the size and sex composition of noble crayfish caught by commercial crayfish "Standard" traps (a more modern method) and baited sticks (an archaic method) in a natural locality during the growing season (May-September).

\section{MATERIAL AND METHODS}

\section{Study area}

The experiment was performed in Světlohorká reservoir, situated in the Šumava Protected Landscape area of South Bohemia. This reservoir was built in the $19^{\text {th }}$ century as storage of water for transport of timber. Presently, Světlohorská reservoir is used for recreational fishing and is a part of the salmonid fishing ground 423049 VOLYŇKA 3 P. The total surface area of this reservoir is $2000 \mathrm{~m}^{2}$ and the mean depth is $2.5 \mathrm{~m}$, respectively. The shore area is mostly composed of stones and gravel and the bottom consists of soft mud without vegetation. East side of shore area consists of many stones, north side is sandy- stony and the other sides are sandy only. The shore area is slightly sloping with large shallow areas.

Světlohorská reservoir is situated in forests where spruce (Picea abies) is the main species. Světlohorská reservoir is situated 944 a.s.l., $49^{\circ} 00^{\prime} \mathrm{N}$ and $13^{\circ} 45^{\prime} \mathrm{E}$, two kilometres from village Lipka. The climate is temperate with higher elevation above sea level, characterized by a long winter and short summer. The ice-free season extends from early May to early November.

Conditions of this reservoir were favourable for crayfish production (Table I). From May to September 2001, the population size of noble crayfish in Světlohorská reservoir was

\section{Table I}

Water quality in the Světlohorská reservoir during June - September 2001.

\section{Tableau I}

Qualité de l'eau dans le réservoir Světlohorská de juin à septembre 2001.

\begin{tabular}{|c|c|}
\hline Parameters & Values \\
\hline Epilimnion temperature & $12.2-18.2^{\circ} \mathrm{C}$ \\
\hline Mean Secchi-depth & 2.5 metres \\
\hline $\mathrm{pH}$ & $5.6-6.9$ \\
\hline Conductivity & $39-41 \mu \mathrm{S} . \mathrm{cm}^{-1}\left(2 \mathrm{O}^{\circ} \mathrm{C}\right)$ \\
\hline Calcium content & $4.4-5.4{\mathrm{mg} . \mathrm{I}^{-1}}^{-1}$ \\
\hline $\mathrm{COD}($ Chemical oxygen demand) & $4.3-11.2 \mathrm{mg} .^{-1}$ \\
\hline $\mathrm{NH}^{4+}-\mathrm{N}$ content & $0.08-0.14{\mathrm{mg} . \mathrm{I}^{-1}}^{-1}$ \\
\hline $\mathrm{NO}_{3}-\mathrm{N}$ content & $0.39-1.32{\mathrm{mg} . \mathrm{I}^{-1}}^{-1}$ \\
\hline $\mathrm{NO}^{2}-\mathrm{N}$ content & $0.002-0.005{\mathrm{mg} . \mathrm{I}^{-1}}^{-1}$ \\
\hline $\mathrm{PO}^{4}-\mathrm{P}$ content & $0.005-0.018 \mathrm{mg}^{-1}$ \\
\hline The saprobity index & $2.09-$ betamesosaprobity level \\
\hline
\end{tabular}

1 The saprobity index was established according to SLÁDEČKOVÁ et al. (1998). 
assessed by Schnabel's mark-recapture method (SCHNABEL, 1938) as 1000 individuals larger than $75 \mathrm{~mm}$. Světlohorská reservoir is locality with a large population of noble crayfish but with poor source of food for crayfish (oligotrophic inlet and short and cold summer).

\section{Crayfish catching}

Trapping of crayfish in Světlohorská reservoir was performed monthly over the growing season, from May to September 2001. Ten traps and ten baited sticks were used for 1.5 hour (from $6 \mathrm{pm}$ to $7: 30 \mathrm{pm}$ ). Cylindrical foldable "Standard traps" as used by WESTMAN, PURSIAINEN and VILKMAN (1978) and KOZÁK, STUPKA and HAMÁČKOVÁ (2001) were used. The length of these traps was $40 \mathrm{~cm}$ and the diameter of $30 \mathrm{~cm}$. The mesh size of nylon net was $10 \mathrm{~mm}$. The diameter of the two circular entrances was $8 \mathrm{~cm}$. The bait was fixed in the middle of the trap. Baited sticks were used according to WESTMAN (1991). Baited sticks were made from a $50 \mathrm{~cm}$ long wood rod and had no terminal hook. Approximately $100 \mathrm{~g}$ of fresh fish (common carp, Cyprinus carpio) was used as bait per trap and stick.

The catch area was about 100 m shoreline on the north and east side of Světlohorská reservoir where most shelters for crayfish occurred. The traps and baited sticks were fastened alternately at $5 \mathrm{~m}$ intervals along the shoreline (baited stick-trap-baited sticketc). Traps were fixed at a depth of 2 meters and baited sticks $20 \mathrm{~cm}$ under the surface. Traps and baited sticks were always set at the same place. Traps and baited sticks were checked every 30 minutes during a 1.5 hour-period; thus, three catches were recorded for each trap and baited stick per month (Thirty catches for traps and thirty catches for baited sticks per month). Crayfish at the baited sticks were caught by a rectangular dip net of $15 \times 20 \mathrm{~cm}$ size with a 30-cm handle. Total body length $(\mathrm{mm})$ and sex were recorded for all catches.

\section{Statistical analyses}

The number, size and sex composition of crayfish caught by traps and baited sticks each month (three catches per month) was compared using ANOVA (Statgraphics, Tukey test, $P<0.01$ ). Catch efficiency (catch per unit effort (CPUE)) was estimated as number of crayfish caught per trap evening or baited stick- evening.

\section{RESULTS}

\section{The effect of growing season}

There was a significantly higher catch for traps in September compared to the other months. For baited sticks the catch was significantly higher in May, June and September as compared to July and August (Figure 1).

\section{Trap and baited stick catch efficiency}

In total, 281 crayfish were caught by traps and baited sticks (49 crayfish by traps and 232 by baited sticks) during the summer 2001 growing season. Of these, 257 crayfish ( 49 crayfish by traps and 208 crayfish by baited sticks) were bigger than $75 \mathrm{~mm}$ representing $25.7 \%$ crayfish of the estimated crayfish population. The number of crayfish with body length longer than $95 \mathrm{~mm}$ (legal-size of crayfish for consumption in some European countries) was 66 (13 by traps and 53 by baited sticks), or $23.5 \%$ of all crayfish caught.

Baited sticks were significantly more effective than traps, except in July when equal numbers of crayfish were caught. Crayfish caught by baited sticks comprised $50 \%$ to $89 \%$ of the total monthly catch of crayfish (Figure 2). 


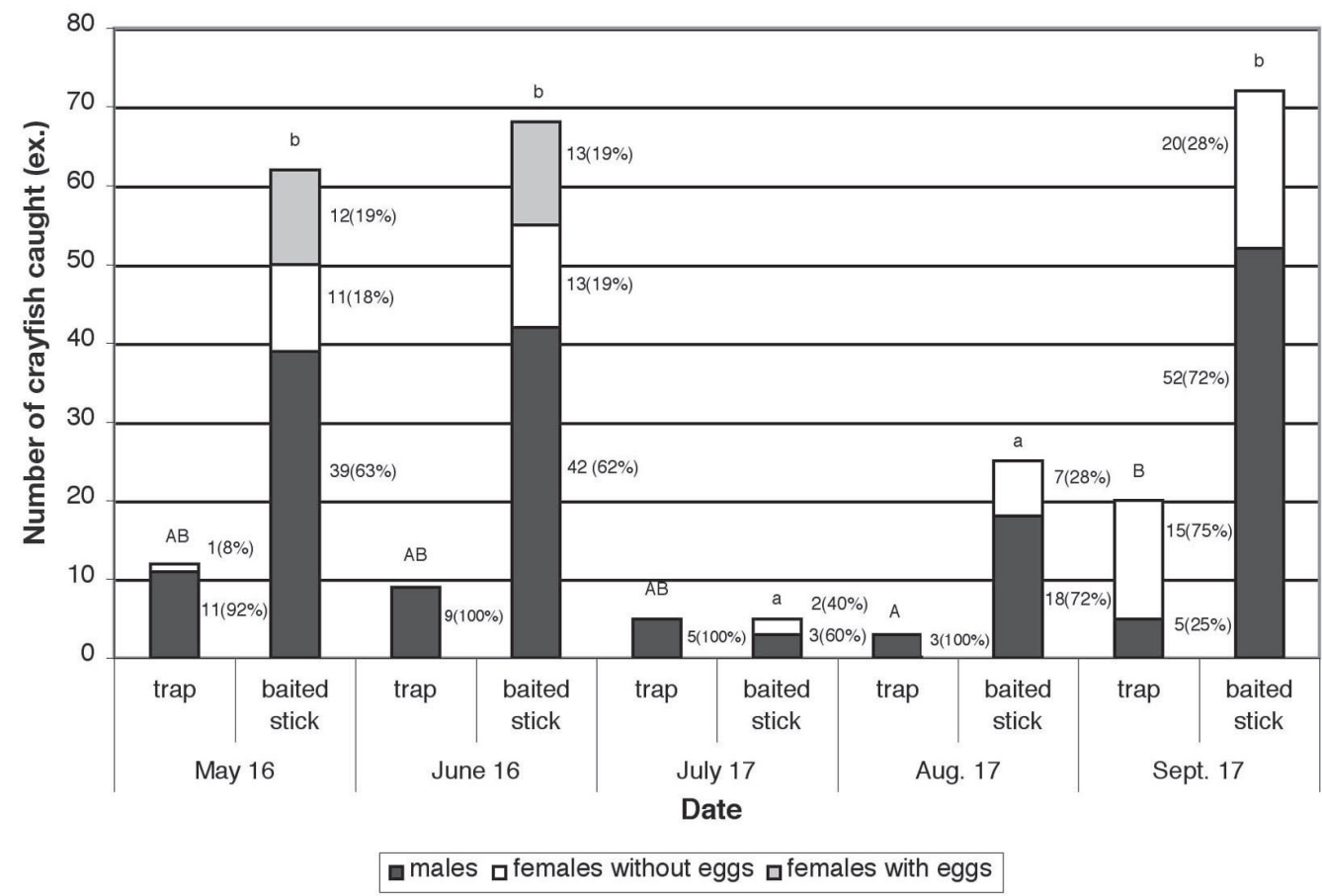

Different superscript shows significant differences between months for the trap and baited stick catches (ANOVA; $\mathrm{P}<0.01$ ).

\section{Figure 1}

Distribution of catches and sex composition of crayfish caught in trap and by baited sticks during the growing season.

\section{Figure 1}

Distribution selon le sexe des écrevisses capturées dans les pièges et dans les bâtons avec appât pendant la saison de croissance.

The CPUE varied between 0.3-2 crayfish per trap - evening and 0.5-7.2 per baited stick - evening, with a minimum in July and maximum in September (Figure 2).

\section{Size and sex composition}

Males dominated in all trap catches, except in September when $75 \%$ of the total catch consisted of females. On the other hand, females were totally absent in traps in June, July and August. Proportions of males and females caught by means of baited sticks were relatively well balanced across the study. Females comprised $28 \%$ to $40 \%$ of baited stick - catches. Special attention was paid to catches of females with eggs during May and June. No females with eggs were caught with traps. By baited sticks, 12 and 13 females with eggs were caught in May and June, respectively (Figure 1).

The body length of males caught in traps and by baited sticks varied between 85$95 \mathrm{~mm}$ and $80-95 \mathrm{~mm}$, respectively. Females of body length between $80-95 \mathrm{~mm}$ were most frequently caught in traps while for baited sticks, the size range was $75-90 \mathrm{~mm}$. Males and females caught by baited sticks were both bigger and smaller (range of body length $60-125 \mathrm{~mm}$ ) than males and females caught by traps (range of body length 75$120 \mathrm{~mm}$ ) (Figure 3 and Figure 4). No significant difference was found between body lengths of males caught in traps and by baited sticks (ANOVA, $F_{\text {krit }}=3.372 ; p=0.0679$ ). 


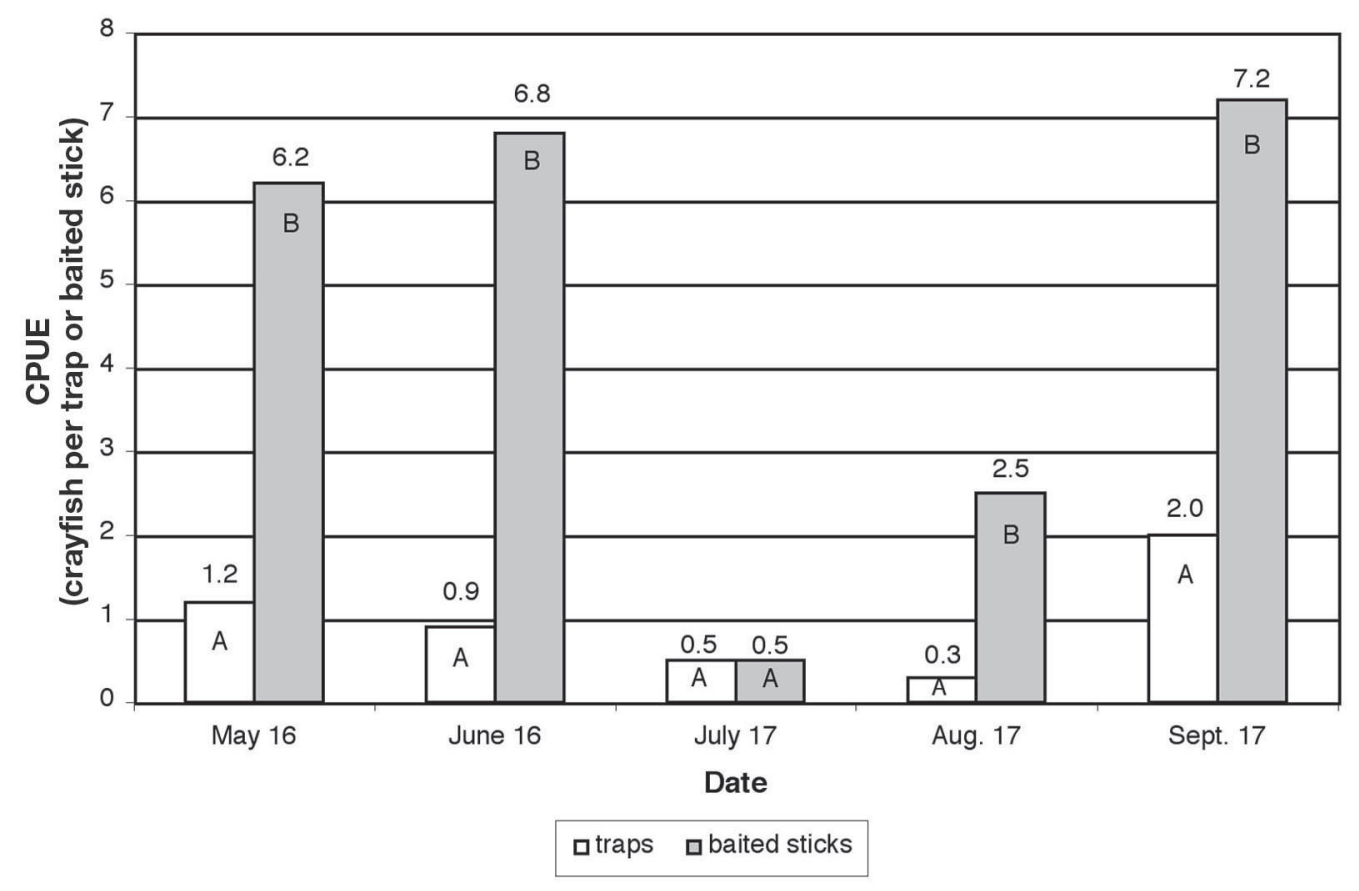

Different superscript shows significant differences between trap and baited stick catches (ANOVA; $P<0.01$ ).

\section{Figure 2}

Comparison of catch efficiency between the trap and baited stick catches during the growing season.

\section{Figure 2}

Comparaison de l'efficacité des captures entre les pièges et les bâtons avec appât pendant la saison de croissance.

Similarly, the body length of females caught in traps and by baited sticks did not differ significantly (ANOVA, $F_{\text {krit }}=1.050 ; p=0.3082$ ).

\section{DISCUSSION}

\section{The effect of growing season}

The first moult of adult males and immature females in the Světlohorská reservoir took place in July. Mature females moulted in August when adult males and immature females also moulted for the second time at this locality. As a result we caught the least number of crayfish by traps and baited sticks in July and August. SKURDAL and QVENILD (1986) and PURSIANEN, SAARELA and WESTMAN (1989) presented similar results from Norway and Finland. POLICAR (1999) also found that the lowest numbers of crayfish were caught in traps in July and September. The large catches of crayfish in September confirm favourable harvest of crayfish after moulting (SKURDAL and TAUGBØL, 1994). The termination date of crayfish harvest is recommended for mid-September because crayfish catches decrease thereafter, and catchability is reduced by falling temperatures and mating activity of crayfish (SKURDAL and TAUGBØL, 1994; SKURDAL and TAUGBØL, 2002). 


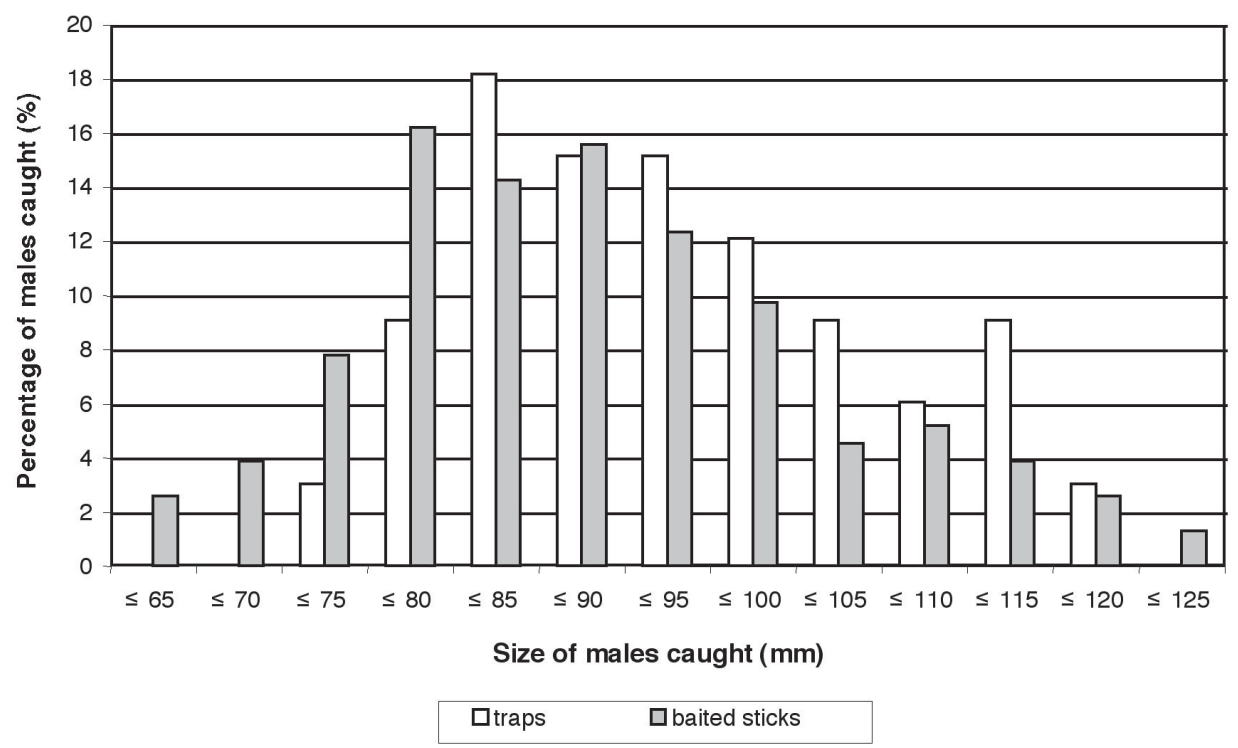

Figure 3

Size composition of males caught in traps and by baited sticks during the growing season.

\section{Figure 3}

Distribution selon la taille des mâles capturés dans les pièges et dans les bâtons avec appât pendant la saison de croissance.

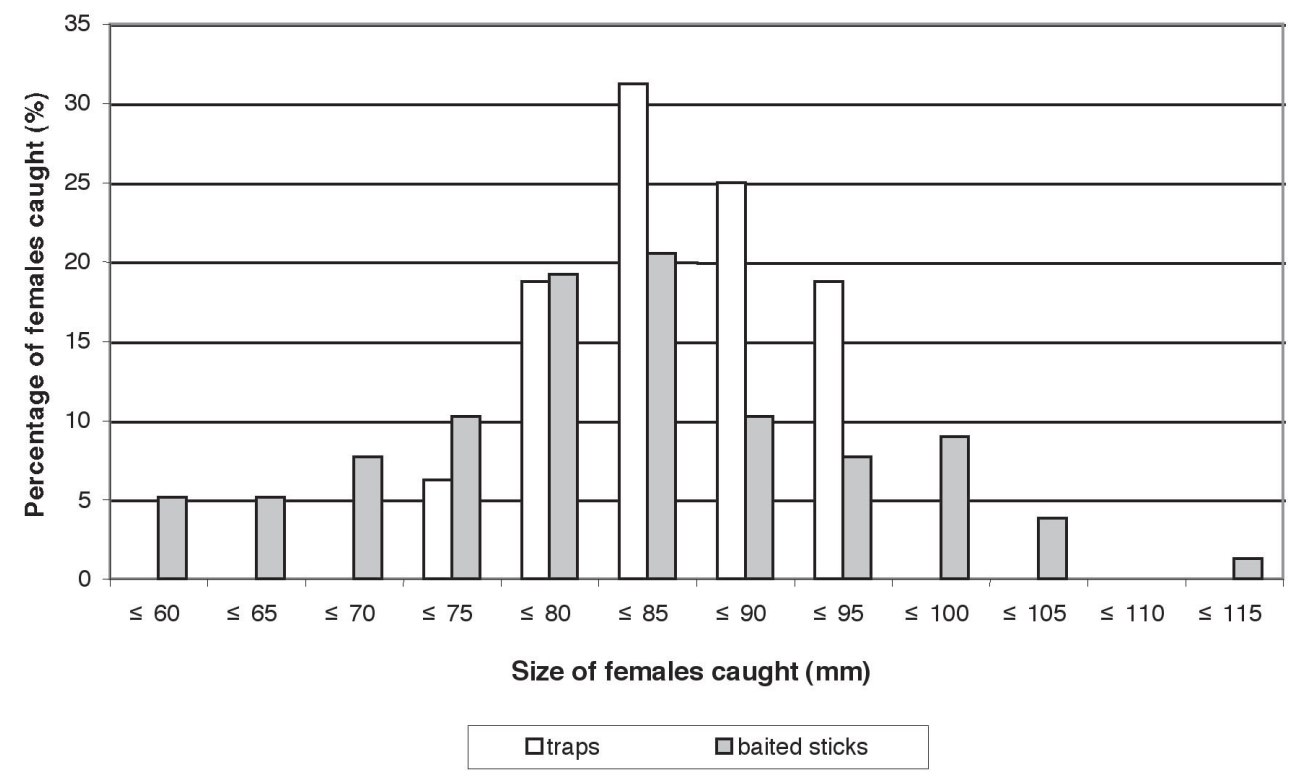

Figure 4

Size composition of females caught in traps and by baited sticks during the growing season.

Figure 4

Distribution selon la taille des femelles capturées dans les pièges et avec les bâtons avec appât pendant la saison de croissance. 


\section{Trap and baited stick catch efficiency}

The catch efficiency and retention ability of commercial crayfish traps have been studied by FJÄLLING (1995), DANIELS and PETROSKY (1998), HUNER (1998) and CAMPBELL and WHISSON (2002). Performance of crayfish traps was studied by BEAN and HUNER (1978), WESTMAN, PURSIAINEN and VILKMAN (1978) and PFISTER and ROMAIRE (1983). Efficiency of traps depends on many factors: trap design (HUNER and PARET, 1995), construction material (BEAN and HUNER, 1978), mesh size (FJÄLLING, 1995), trap colour (FOUILLAND and ODILE, 1998), number and size of entrances (BEAN and HUNER, 1978; WESTMAN, PURSIAINEN and VILKMAN, 1978; SKURDAL et al., 1995), type of bait (KUTKA et al., 1992; BURNS and AVAULT, 1991; TAUGBØL et al., 1997) and time of trap exposure (WESTMAN, PURSIAINEN and VILKMAN, 1978; KOZÁK, STUPKA and HAMÁĆKOVÁ, 2001).

"Standard traps" were used in our study as one of the most cost-effective methods of harvesting and sampling of crayfish (JUSSILA, 1995). Efficiency of these traps was compared with baited sticks, which are used only for recreational crayfish catching today. During our study, we found better efficiency of baited sticks than that of traps in the majority of cases. These results were very surprising. Catching by traps had a recreational character (very low harvesting of crayfish) therefore were comparable to baited sticks. Low efficiency of traps in this study was most likely caused by unsuitable and short time of fishing. EDSMAN and SÖDERBÄCK (1999) recommend setting the traps just before dusk and empty them next morning while ROMAIRE and PFISTER (1983) recommend checking traps after six hours.

Catch per unit effort (CPUE) is an important indicator of crayfish catch. Many authors have established the CPUE during the trapping season (SKURDAL et al., 1993; PURSIAINEN and WESTMAN, 1995; SKURDAL et al., 1995; SKURDAL, QVENILD and TAUGBØL, 1995). In these Scandinavian studies, the CPUE varied during the trapping season. The trap CPUE was the highest at the beginning of the catching season and then decreased until the second moult in late August. Then trap effort increased at the beginning of September and decreased again after September 15 as low temperature reduced catches (SKURDAL et al., 1993). Our trap CPUE showed the same pattern during the growing season of 2001. Baited stick CPUE was high in May and increased until June. Thereafter baited stick CPUE decreased in July and increased in September again.

\section{Size and sex composition}

Size and sex composition of noble crayfish in trap catches were studied by SKURDAL, QVENILD and TAUGBØL (1995) in Norway prior to and following the fishing season. Size and sex composition are influenced by a number of factor such as water temperature, moulting, mating, carrying offspring, etc. (SKURDAL, QVENILD and TAUGBØL, 1995). Traps are size and sex selective, catching small crayfish less effectively (ABRAHAMSSON, 1966 and QVENILD and SKURDAL, 1989) and trap mesh size influences body length of crayfish caught (WESTMAN, PURSIAINEN and VILKMAN, 1978; QVENILD and SKURDAL, 1989; SKURDAL et al., 1993; SKURDAL and TAUGBØL, 1994).

Females carry their offspring until July. During this period females have low catchability in traps (ABRAHAMSSON, 1983). Following the hatching and liberation of juveniles, females moult in August (SKURDAL et al., 1995a) and therefore no females were caught by traps and a few females were caught by baited sticks during this period. Baited sticks were more successful in catching all females (with or without eggs) from May to July. Females with eggs and immature females after moult are very cautious about entering traps while crayfish coming to baited sticks are likely less cautious as there are no physical obstacles for them to overcome. 
Male dominance in trap catches of unexploited populations of crayfish was reported by ABRAHAMSSON (1966). Conversely, SKURDAL, QVENILD and TAUGBØL (1995) found fewer males in traps in heavily exploited population of crayfish in Lake Steinsfjorden for a number of years. As autumn progresses a shift in composition of trap catches has been noted, with an increasing fraction of females (ABRAHAMSSON, 1983; TAUGBØL and SKURDAL, 1989; SKURDAL, QVENILD and TAUGBØL, 1995). These findings were confirmed by our study as most females were caught in trap catches in September.

\section{CONCLUSION}

In this study, baited sticks were found to be the more effective method during most of the growing season, (with exception of July). Lower efficiency of traps was apparently related to unsuitable trapping time interval as well as the short time of exposure. Catching by traps had recreational character in our study (very low harvesting of crayfish) therefore was comparable to baited sticks which are not important for crayfish harvesting industry in Europe. The use of baited sticks was more successful than using traps for catching females, especially for catching females with eggs. No females with eggs were caught in traps.

Due to high catch efficiency, baited sticks can be considered as an appropriate catching gear and good alternative or supplement to traps, especially in monitoring projects where short-time catching effort is required.

\section{ACKNOWLEDGEMENTS}

This investigation was supported by MSMT CR project No. MSM 6007665809. Our thanks to Premek HAMR (Canada) for English corrections and Valérie MANIGLIER (France) for the translation of the French abstract.

\section{REFERENCES}

ABRAHAMSSON S., 1966. Dynamics of an isolated population of the crayfish Astacus astacus Linné. Oikos, 17, 96-107.

ABRAHAMSSON S., 1983. Trappability, locomotion and diel pattern of activity of the crayfish Astacus astacus and Pacifastacus leniusculus Dana. Freshwater Crayfish, 5, 239-253.

ADÁMEK Z., 1998. Problematika chovu raků s ohledem na zákon o ochraně prírody 114/92 Sb. / Problems of crayfish farming with respect for the nature protection act. Bulletin VÚRH Vodňany, 3, 112, in Czech with English abstract.

BEAN R., HUNER J., 1978. An evaluation of selected crayfish traps and trapping methods. Freshwater crayfish, 4, 141-151.

BURNS C.M., AVAULT J., 1991. Effects of bait composition and of water temperature on harvestability of crayfish baits. Journal of Applied Aquaculture, 1, 57-64.

CAMPBELL L., WHISSON G., 2002. Catch efficiency of five freshwater crayfish traps in southwest Western Australia. Freshwater crayfish, 13, 58-66.

CUKERZIS J.M., 1988. Astacus astacus in Europe. In: Freshwater Crayfish: Biology, Management and Exploitation, (eds HOLDICH D.M. and LOWERY R.S.), Croom Helm, London, 309-340. 
DANIELS W.H., PETROSKY B.R., 1998. The effects of different harvesting methods on the production characteristic of the eastern white river crayfish Procambarus acutus. Aquaculture'98, Book of Abstracts, 133.

ĎURIŠ Z., KOZÁK P., 2000. The "Golden Crayfish" in the Czech Republic. Crayfish News, 22(1), 8-9.

EDSMAN L., SÖDERBÄCK B., 1999. Standardised sampling methodology for crayfish - The Swedish protocol. Freshwater crayfish, 12,705-713.

FEDOTOV V.P., 1993. Razveděnie rakov / The crayfish culture. Sankt Petěrburg, 106 p., in Russian only.

FJÄLLING A., 1995. Crayfish traps in Swedish fisheries. Freshwater crayfish, 8, 201- 214.

FOUILLAND E., ODILE F., 1998. Effects of some operational factors on Macrobrachium (Decapoda, Palaemonidae) sampling using small "wicker traps". Fisheries Research, 34, 87-92.

HAGER J., 1996. Edelkrebse/Freshwater Crayfish. Leopold Stocker Verlag, Graz Stuttgart, 128 p., in German only.

HOLDICH D.M., 1988. Crayfish - an introduction. In: Freshwater Crayfish: Biology, Management and Exploitation (eds HOLDICH D.M. and LOWERY R.S.), Croom Helm, London, 1-7.

HOLDICH D.M., 2002. Background and Functional Morphology. In: Biology of Freshwater Crayfish, (ed. HOLDICH D.M), Blackwell Science Ltd., London, 3-29.

HUNER J.V., 1998. Evaluation of trap density and type for harvesting crayfish Procambarus spp. from small ponds. Journal of the Word Aquaculture Society, 29, 104-107.

HUNER J.V., PARET J., 1995. Harvest of crayfish (Procambarus spp.) from a South Louisiana commercial pond: effectivity of different baits and species composition. Freshwater Crayfish, 8, 376-390.

JUSSILA J., 1995. On the costs of trapping in Central Finland. Freshwater Crayfish, 8, 215-227.

KELLER M., 1987. Finding a profitable population density in rearing summerlings of European crayfish Astacus astacus L. Freshwater crayfish, 7, 259-266.

KOZÁK P., STUPKA Z., HAMÁČKOVÁ J., 2001. Vyhodnocení únikovosti raků z odchytových pastí (vrší) / Evaluation of crayfish escapes from crayfish traps. Bulletin VÚRH Vodňany, 3, 124-128, in Czech with English abstract.

KRUPAUER V., 1968. Zlatý rak / The Golden crayfish. Nakladatelství České Budějovice, 108 p., in Czech only.

KUTKA F.J., RICHARDS C., MERICK G.W., DE VORE P.W., MC DONALD M.E., 1992. Bait preference and trapability of two common crayfishes in northern Minnesota. Progressive Fish-Culturist, 54, 250-254.

LEHTONEN J.U.E., 1974. Crayfish catching in Finland in the 19th century. Suomen Kalatalous, 47,1-6, in Finnish with English and Norwegian abstract.

PFISTER V.A., ROMAIRE R.P., 1983. Catch efficiency and retentive ability of commercial crayfish traps. Aquacultural Engineering, 2, 101-118.

POLICAR T., 1999. Vliv ročního období na velikost a složení úlovků raka říčního (Astacus astacus L.) / The effect of growing season on quantity and sex ratio per noble crayfish (Astacus astacus L.) catch. Bulletin VúRH Vodňany, 3, $123-126$, in Czech with English abstract. 
PURSIANEN M., SAARELA M., WESTMAN K., 1989. The reproductivity of female noble crayfish Astacus astacus in a northern oligotrophic lake. Freshwater Crayfish, 7, 155-164.

PURSIAINEN M., WESTMAN K., 1995. The factors affecting the noble crayfish (Astacus astacus) catch per unit effort (C.P.U.E.). Freshwater Crayfish, 8, 713-714.

QVENILD T., SKURDAL J., 1989. Does increased mesh size reduce non-legalized fraction of Astacus astacus in trap catches? Freshwater Crayfish, 7, 277-284.

ROMAIRE R.P., PFISTER V.A., 1983. Effects of trap density and diel harvesting frequency on catch of crawfish. North American Journal of Fisheries Management, 3, 419-424.

SCHNABEL Z.E., 1938. The estimation of the total fish population of a lake. American Mathematics Monographs, 45, 348-352,

SLÁDEČKOVÁ A., SLÁDEČEK V., FREMROVÁ L., ČERMÁK O., 1998. Jakost vod Biologický rozbor - Stanovení saprobního indexu / The quality of water - Biological analyse - The establishment of saprobity index. ČSN 75 7716. Český normalizační institut, Praha, 174 p., in Czech only.

SKURDAL J., QVENILD T., 1986. Growth, maturity and fecundity of Astacus astacus in Lake Steinsfjorden, SE Norway. Freshwater Crayfish, 6, 182-186.

SKURDAL J., QVENILD T., TAUGBØL T., GARNAS E., 1993. Long term study of exploitation, yield and stock structure of noble crayfish Astacus astcus in Lake Steinsfjorden. Freshwater Crayfish, 9, 118-33.

SKURDAL J., TAUGBØL T., 1994. Do we need harvest regulations for European crayfish? Reviews in Fish Biology and Fisheries, 4, 461-485.

SKURDAL J., QVENILD T., TAUGBØL T., GARNAS E., 1995. Can catch per unit effort data (CPUE) forecast yield in an exploited noble crayfish Astacus astacus L. population? Freshwater Crayfish, 8, 257-264.

SKURDAL J., QVENILD T., TAUGBØL T., 1995. Size and sex composition of noble crayfish Astacus astacus. in trap catches in lake Steinsfjorden, S.E. Norway: effect of exploitation. Freshwater Crayfish, 8, 249-256.

SKURDAL J., TAUGBØL T., BURBA A., EDSMAN L., SØDERBACK B., STYRRISHAVE B., TUUSTI J., WESTMAN K., 1999. Crayfish introductions in the Nordic and Baltic countries. In: Crayfish in Europe as Alien Species. How to Make the Best of a Bad Situation? (eds GHERARDI F. and HOLDICH D.M.), A.A. Balkema, Rotterdam, 193219.

SKURDAL J., TAUGBØL T., 2002. Astacus. In: Biology of Freshwater Crayfish. (ed. HOLDICH D.M), Blackwell Science Ltd., London, 467-510.

SCHNABEL Z.E., 1938. The estimation of the total fish population of a lake. American Mathematics Monographs, 45, 348-352.

SWAHN J.-Ö., 2004. The cultural history of crayfish. In: TAUGBØL T. and SOUTYGROSSET C., 2004: European native crayfish with a special focus on Astacus astacus: linking socioeconomics and conservation, CRAYNET, volume 2, Bull. Fr. Pêche Pisc., 372-373, 243-263.

TAUGBØL T., SKURDAL J., 1989. Effect of indoor, culture conditions on maturation and fecundity of wild caught female noble crayfish Astacus astacus L. Aquaculture, 81, $1-12$.

TAUGBØL T., SKURDAL J., BURBA A., MUNOZ C., SAEZ-ROYUELA M., 1997. A test of crayfish predatory and non-predatory fish species as bait in crayfish traps. Fisheries Management and Ecology, 4, 127-134. 
WESTMAN K., PURSIAINEN M., VILKMAN R., 1978. A new folding trap model that prevents crayfish from escaping. Freshwater crayfish, 4, 236-242.

WESTMAN K., PURSIAINEN M., WESTMAN P., 1990. Status of crayfish stocks, fisheries, diseases and culture in Europe. Finnish Game and Fisheries Research Institute, Report No 3, Helsinki, Finland.

WESTMAN K., 1991. The crayfish fishery in Finland-its past, present and future. Finnish Fisheries Research, 12, 187-216. 